Vol. 12 (2003): 95-105.

\title{
Yield potential of chive: Effects of cultivar, plastic mulch and fertilisation
}

\author{
Terhi Suojala \\ MTT Agrifood Research Finland, Plant Production Research, Horticulture, Toivonlinnantie 518, \\ FIN-21500 Piikkiö, Finland, e-mail: terhi.suojala@mtt.fi
}

\begin{abstract}
Chive is a perennial herb, growing also natural in Finland. Commercial production of the herb is very small in our country, but large amounts of chive are imported. This fact has aroused interest in investigating the opportunities of producing chive using modern cultivation techniques. Effects of cultivar, plastic mulch as ground cover and fertilisation on yield were studied in field experiments over three years. In the experiments, the most productive cultivars or populations (a Finnish population "Hankoniemi", a Dutch population "Tavallinen" and a German cultivar 'Grolau') produced 10-20\% higher yields than the less productive cultivars. There were no clear differences in the yield quality between the cultivars. Black plastic mulch was effective in increasing yield, controlling weeds and maintaining soil moisture. For fertilisation, the experiments revealed the high nutrient demand of chive. After the basic soil fertilisation, weekly fertigation with a NPK fertiliser at a higher nitrogen dose (10-15 $\mathrm{kg} \mathrm{ha}^{-1} \mathrm{~N}$ per week) resulted in higher biomass production than fertigation with nitrogen alone and/or a half nitrogen dose. In the years following the planting, the annual uptakes in yield were $185-200 \mathrm{~kg} \mathrm{ha}^{-1}$ for nitrogen, $17-20 \mathrm{~kg} \mathrm{ha}^{-1}$ for phosphorus, and $120-140 \mathrm{~kg} \mathrm{ha}^{-1}$ for potassium in the most intensively fertilised treatment producing the highest yield. The results show that chive is feasible for commercial production with modern cultivation techniques.
\end{abstract}

Key words: Allium schoenoprasum L., chives, fertigation, culinary herbs, mulches, nitrogen, cultivars

\section{Introduction}

Chive (Allium schoenoprasum L.) is a traditional perennial herb grown in nearly all home gardens in Finland. It also grows in natural habitats in coastal Finland, and is thus well adapted to Finnish conditions. However, large amounts of freeze-dried or dried chive are imported to Finland for food industry and retail. Our research aimed at exploring the opportunities of producing chive in larger areas and at developing modern cultivation techniques for commercial production.

Reports on previous research on growing chive are very scarce. All over the world, chive 
Suojala, T. Yield potential of chive

is only a minor crop. According to Poulsen (1990), the commercial production area is globally no more than 1,000 hectares. Breeding of chive has concentrated on cultivars suitable for forcing in greenhouse, not for field production (Poulsen 1990). Cultivars grown in open field are usually not uniform. Some hybrid cultivars have been bred which have higher plants, larger leaves and higher yield than openpollinated cultivars (Tatlioglu and Wricke 1980).

Fertilisation demand was studied by Hartmann (1966), but since then, great changes have taken place as far as cultivars and cultivation technology are concerned. Poulsen (1990) gave the following instructions for fertilisation: $11 \mathrm{~kg} \mathrm{ha}^{-1} \mathrm{P}$ and $83 \mathrm{~kg} \mathrm{ha}^{-1} \mathrm{~K}$ in spring, and thereafter nitrogen at the rate of $10-12 \mathrm{~kg} \mathrm{ha}^{-1}$ per week, totalling $220 \mathrm{~kg} \mathrm{ha}^{-1}$ per year.

The aim of the present research was to evaluate the yield potential of chive when using modern cultivation techniques. The more specific objectives were to analyse which cultivars produce the highest yield of good quality and to estimate the benefits of using black plastic as mulch. In another experiment, the objective was to analyse the amount of nutrients taken away from field in yield and to develop a suitable fertilisation programme for the seasons following the planting.

\section{Material and methods}

Field experiments were conducted at the MTT Horticulture facilities at Piikkiö $\left(60^{\circ} 23^{\prime} \mathrm{N}\right.$, $22^{\circ} 30^{\prime} \mathrm{E}$ ). The soil was fine sand, rich in organic matter. Oats were grown as precrop. Prior to planting, the soil was enriched with dark peat (10 $\mathrm{cm}$ layer) that was limed $\left(10 \mathrm{~kg} \mathrm{~m}^{-3}\right.$ peat) and incorporated into soil. For basic fertilisation, the whole experimental area was fertilised with a compound fertiliser including $60 \mathrm{~kg} \mathrm{ha}^{-1} \mathrm{~N}$, $24 \mathrm{~kg} \mathrm{ha}^{-1} \mathrm{P}$ and $102 \mathrm{~kg} \mathrm{ha}^{-1} \mathrm{~K}$ (plus other macro- and micronutrients). In addition, to improve the nutrient status of the soil, micronutrients were added in form of a special fertiliser. Soil nutrient contents prior to and in the course of the experiment are presented in Table 1 .

Table 1. Soil nutrient contents (mean \pm standard deviation, if available) before the experiment and at the end of each growing season.

\begin{tabular}{|c|c|c|c|c|c|c|c|c|c|c|}
\hline Date & $\mathrm{pH}$ & $\begin{array}{l}\text { Conductivity } \\
10 \times \mathrm{mS} \mathrm{cm}^{-1}\end{array}$ & $\begin{array}{l}\mathrm{Ca} \\
\mathrm{mg} \mathrm{l}^{-1}\end{array}$ & $\begin{array}{l}\mathrm{K} \\
\mathrm{mg} \mathrm{l}^{-1}\end{array}$ & $\begin{array}{l}\mathrm{Mg} \\
\mathrm{mg} \mathrm{l}^{-1}\end{array}$ & $\begin{array}{l}\mathrm{P} \\
\mathrm{mg} \mathrm{l}^{-1}\end{array}$ & $\begin{array}{l}\mathrm{B} \\
\mathrm{mg} \mathrm{l}^{-1}\end{array}$ & $\begin{array}{l}\mathrm{Cu} \\
\mathrm{mg} \mathrm{l}^{-1}\end{array}$ & $\begin{array}{l}\mathrm{Mn} \\
\mathrm{mg} \mathrm{l}^{-1}\end{array}$ & $\begin{array}{l}\mathrm{Zn} \\
\mathrm{mg} \mathrm{1^{-1 }}\end{array}$ \\
\hline 25 Apr 2000 & $6.8 \pm 0.14$ & $0.8 \pm 0.07$ & $1425 \pm 7.1$ & $111 \pm 0.7$ & $126 \pm 5.0$ & $17 \pm 0.7$ & $0.4 \pm 0.07$ & $4.1 \pm 0.07$ & $5.5 \pm 0.14$ & $1.6 \pm 0.29$ \\
\hline \multicolumn{11}{|c|}{ Fertilisation experiment (NPK2) } \\
\hline 7 Sep 2000 & 6.3 & 1.6 & 1603 & 108 & 185 & 20 & & & & \\
\hline 6 Sep 2001 & 6.5 & 1.0 & 1200 & 78 & 147 & 16 & & & & \\
\hline \multicolumn{11}{|c|}{23 Aug 2002} \\
\hline N1 & 6.7 & 0.6 & 1330 & 41 & 134 & 12 & & & & \\
\hline $\mathrm{N} 2$ & 6.7 & 1.2 & 1540 & 51 & 175 & 14 & & & & \\
\hline NPK1 & 6.6 & 0.8 & 1190 & 69 & 150 & 11 & & & & \\
\hline NPK2 & 6.8 & 1.1 & 1240 & 151 & 152 & 22 & & & & \\
\hline \multicolumn{11}{|c|}{ Cultivar experiment } \\
\hline 23 Aug 2002 & $6.8 \pm 0.28$ & $1.0 \pm 0.07$ & $1450 \pm 141$ & $85 \pm 12.4$ & $170 \pm 12$ & $16 \pm 0.7$ & & & & \\
\hline
\end{tabular}

$\mathrm{N} 1$ - nitrogen fertiliser, single dose

$\mathrm{N} 2$ - nitrogen fertiliser, double dose

NPK1 - NPK fertiliser, single dose

NPK2 - NPK fertiliser, double dose 
Vol. 12 (2003): 95-105.

Table 2. Monthly mean temperature and precipitation in the experimental years and the long-term averages.

\begin{tabular}{lrrrrrrrr}
\hline Month & \multicolumn{3}{c}{ Mean temperature, ${ }^{\circ} \mathrm{C}$} \\
& 2000 & 2001 & 2002 & $1971-90$ & 2000 & 2001 & 2002 & $1971-90$ \\
\hline April & 6.0 & 5.0 & 5.2 & 3.1 & 38 & 58 & 4 & 37 \\
May & 10.2 & 9.1 & 11.4 & 9.6 & 26 & 20 & 6 & 35 \\
June & 13.5 & 14.0 & 16.3 & 14.4 & 51 & 37 & 61 & 47 \\
July & 16.3 & 19.6 & 18.7 & 16.6 & 131 & 101 & 115 & 77 \\
August & 15.1 & 16.2 & 18.5 & 15.3 & 68 & 54 & 9 & 78 \\
September & 9.5 & 12.3 & 10.9 & 10.4 & 21 & 119 & 8 & 64 \\
\hline
\end{tabular}

Chive was propagated from seeds sown in greenhouse on 11 April 2000. Eight seeds per a $5 \times 5 \mathrm{~cm}$ cell were sown, and typically, 5-7 plants emerged. Plants were grown in greenhouse for six weeks and planted to the open field on 22 and 23 May. They were planted in double rows, with a distance of $30 \mathrm{~cm}$ between the rows and $20 \mathrm{~cm}$ between the plants. Double rows were $120 \mathrm{~cm}$ apart. Drip irrigation tubes were installed in the middle of the double row at the depth of $5 \mathrm{~cm}$.

Meteorological data of the experimental years are given in Table 2. Growing seasons 2001 and 2002 were warmer than the long-term average. Precipitation in the first two seasons was close to the average values, but growing season 2002 was characterised by an extremely low precipitation in early and late summer and high rainfall in July.

Soil moisture content was monitored by four tensiometers, installed in the depths of 15 and $40 \mathrm{~cm}$ in the cultivar experiment. Irrigation threshold was set at $0.05 \mathrm{MPa}$. However, soil tension never exceeded $0.02 \mathrm{MPa}$ due to rainfall and water given by fertigation (3.9 litres per 1 row metre at each fertigation).

\section{Cultivar experiment}

Six cultivars or populations were included in the cultivar experiment. Four of them were proper cultivars, 'Finbladet' and 'Triumpf' bred by the Danish company L. Daehnfeldt and 'Grolau' and
'Wilau' bred by the German company Sperli. "Hankoniemi" was a Finnish population taken into cultivation in 1920 s, and "Tavallinen" was a cultivated Dutch population. The experimental design included mulch (black plastic vs. no mulch) in whole plots and cultivar in subplots. Whole plots were arranged in randomised complete block design with four replicates. Subplots with a width of one row $(1.2 \mathrm{~m})$ and length of 6 metres were separately randomised within each whole plot.

\section{Fertilisation experiment}

In the fertilisation experiment, different fertilisation treatments were compared after an uniform pre-planting fertilisation. The aim was to find out if adding nitrogen alone is sufficient or if other nutrients are needed as well. Also, the effects of two different nitrogen doses were compared. The four fertilisation programmes were initiated after the first harvest in 2000. Fertigation was accomplished by drip irrigation. Fertilisation treatments were separately randomised in four blocks. The plots were one row $(1.2 \mathrm{~m})$ wide and 14 metres long. Cultivar Grolau was used in the experiment, and the growing beds were covered by black plastic.

Fertilisation treatments were as follows (see Table 3): nitrogen fertiliser, single dose (N1), nitrogen fertiliser, double dose (N2), NPK fertiliser, single dose (NPK1) and NPK fertiliser, double dose (NPK2). The amount of nitrogen 
Suojala, T. Yield potential of chive

Table 3. Dosage of N, P and $\mathrm{K}$ in different fertilisation treatments and in the cultivar experiment.

\begin{tabular}{lllllll}
\hline Year & \multirow{2}{*}{ Number of fertilisations } & \multicolumn{2}{l}{ N-P-K $\left(\mathrm{kg} \mathrm{ha}^{-1}\right)$ in different treatments } & & \\
& & N1 & N2 & NPK1 & NPK2 & Cultivar exp. \\
\hline \multirow{2}{*}{2000} & Basic fertilization & $60-24-102$ & $60-24-102$ & $60-24-102$ & $60-24-102$ & $60-24-102$ \\
& 4 fertigations & $20-0-0$ & $40-0-0$ & $20-3.5-15$ & $40-7-30$ & $20-0-0$ \\
& Total in 2000 & $80-24-102$ & $100-24-102$ & $80-27.5-117$ & $100-31-132$ & $80-24-102$ \\
2001 & 16 fertigations & $97-0-0$ & $195-0-0$ & $97-16-67$ & $194-32-134$ & $97-12-52$ \\
2002 & 14 fertigations & $85-0-0$ & $170-0-0$ & $84-15-78$ & $167-30-156$ & $84-15-78$ \\
\hline
\end{tabular}

$\mathrm{N} 1$ - nitrogen fertiliser, single dose

$\mathrm{N} 2$ - nitrogen fertiliser, double dose

NPK1 - NPK fertiliser, single dose

NPK2 - NPK fertiliser, double dose

used in treatments N1 and NPK1 was doubled in treatments $\mathrm{N} 2$ and NPK2. The amounts of nutrients given varied between years; in 2000, fertigation started first in July after the initial harvest. In the second year, doses were increased due to the low nitrogen status in soil. In 2002, fertigation ceased after the last harvest in August, and consequently, the fertigation times were fewer and the total nutrient amount was lower than in the preceeding year (Table 3).

Fertigation was given once a week after the first harvest in the planting year, continuing to the last harvest in each year. In the second and third years, fertigation started in the beginning of May and, only at the time of flower stalk growth, one fertigation was omitted. Calcium nitrate (nitrate-N 15.5\%, Ca 19\%, Kemira Agro Ltd., Finland) was used as nitrogen fertiliser. In NPK treatments in 2000 and 2001, a commercially available compound fertiliser (Puutarhan täyslannos: nitrate-N 7.6\%, urea-N 7.1\%, P 5\%, K 21\%, S $1.8 \%, \mathrm{Mg} 1.4 \%$, Fe $0.1 \%$, B $0.02 \%, \mathrm{Cu} 0.01 \%$, Mn $0.1 \%, \mathrm{Zn} 0.01 \%$, Mo $0.002 \%$, Co $0.001 \%$, Kemira Agro Ltd.) was applied every other week and calcium nitrate the other weeks. In 2001, NPK fertiliser was changed in order to improve the magnesium and potassium supply. Mixture of a compound fertiliser (Puutarhan hydrolannos: nitrate-N 6\%, $\mathrm{P} 5 \%, \mathrm{~K} 26 \%, \mathrm{~S} 4 \%, \mathrm{Mg} 2.7 \%$, Fe $0.2 \%$, B $0.02 \%, \mathrm{Cu} 0.01 \%, \mathrm{Mn} 0.1 \%, \mathrm{Zn} 0.01 \%$,
Mo $0.002 \%$, Co $0.001 \%$, Kemira Agro Ltd., Finland) and magnesium nitrate $(\mathrm{Mg} 9.5 \%$, nitrate-N 11\%) was applied every other week, alternating with calcium nitrate.

\section{Measurements}

Yield was harvested in $6 \mathrm{~m}^{2}$ plots in 2000 and in $3.6 \mathrm{~m}^{2}$ plots in the following years. There were two harvests in 2000 and four harvests in 2001 and 2002 each. Yield from the mulched plots in the cultivar experiment was graded in order to estimate the saleable percentage of yield. Samples were taken from every yield to analyse the dry matter content. In the cultivar experiment, they were taken from the mulched plots, and in the fertilisation experiment from the plots with treatment NPK2. Samples were dried at $70^{\circ} \mathrm{C}$ to constant weight.

In the fertiliser experiment, soil nutrient content was monitored by samples taken from the vicinity of the chive rows at 2-4 weeks' intervals. Soil mineral nitrogen was analysed reflectometrically using Reflectoquant Ammonium and Nitrate Tests (Merck, Germany) and other nutrients by advisory soil tests (Soil Analysis Service Ltd., Mikkeli, Finland). Plant samples taken for dry matter analyses at each harvest were later on analysed for N, P and K concentrations in order to estimate the amount of nutrients taken away from field in yield. $\mathrm{N}$ was meas- 
Vol. 12 (2003): 95-105.

ured by means of the macro-Kjeldahl method. P and $\mathrm{K}$ samples were ashened at $450^{\circ} \mathrm{C}$ and the ashes were dissolved in $\mathrm{HCl}$. P was measured colorimetrically using an ammonium-vanadatemolybdate method and $\mathrm{K}$ was determined by an atomic absorption spectrophotometer. Plant nutrient analyses were performed at MTT Soils and Environment.

\section{Statistical analysis}

Variables subjected to the analysis of variance were total yields at each harvest and the annual total yields in both experiments. In the cultivar experiment, the saleable percentage of yield from the mulched plots was also analysed.

In the cultivar experiment, a mixed model for split-plot design was used for the analysis of total yield. Saleable percentages were only calculated for the mulched plots, and consequently, only the effect of cultivar as a fixed factor was included in the model (assuming block as a random factor). Similarly, the fertilisation experiment was analysed using a mixed model with treatment as a fixed factor and block as a random factor. Estimated means for cultivars were further compared by Tukey's test. In the fertilisation experiment, contrasts were utilised to compare the overall effect of nitrogen vs. NPK fertiliser (N1 and N2 vs. NPK1 and NPK2) and single vs. double dose (N1 and NPK1 vs. N2 and NPK2).

The SAS MIXED procedure (Littell et al. 1996) was used to fit the model by the restricted maximum likelihood estimation method. Residual analyses did not indicate any cross departures from the assumptions of the models. In the first yield in 2001, data from mulched plots in block 4 were omitted due to a fertilisation error. In addition, there was one observation missing in the data on the saleable percentages.

Nutrient concentrations and uptakes were measured only in one treatment and no statistical analyses were performed. Data are presented as means over four replicates $( \pm$ standard deviation).

\section{Results}

\section{Mulch}

Use of black plastic mulch turned out to be profitable both for yield and weed control. The only exception to this positive influence was the statistically significantly lower yield in the first harvest in the planting year: plastic mulch decreased the yield by $15 \%$ in comparison with bare soil (Table 4). In the second and third years, mulch increased the yield, although the effect was not always statistically significant. The greatest positive effect of mulch was measured in the first harvest in 2001: yield from the mulched plots was up to $63 \%$ higher than yield from the bare soil. This was the only harvest in which the effect of mulch was not similar for all cultivars. This interaction was due to the unusual response of cultivar Triumf which, in contrast to the other cultivars and populations, did not benefit from usage of mulch.

\section{Cultivars}

Cultivars and populations showed differences in yield each year (Table 4). The effect of cultivar on yield was statistically significant for the second harvest in the planting year and most harvests in the following years. Moreover, cultivars showed similar differences in the annual total yields. Cultivars and populations could be divided into two groups: "Tavallinen", "Hankoniemi" and 'Grolau' produced higher yields each year, whereas 'Finbladet', 'Triumf' and 'Wilau' had 10-20\% lower total yields.

Saleable proportion of total yield was calculated for yields of mulched plots. There were very few statistically significant differences in the saleable percentage between cultivars. In the second yield in 2000, "Hankoniemi" had the lowest saleable percentage $(88.0 \%$, standard error of the mean $=$ SEM 1.15) but the differences were not very large (Fig. 1). In the first yield in 2001, "Hankoniemi", 'Triumf' and 'Finbladet' had the 
Suojala, T. Yield potential of chive

Table 4. Total yields (1 $\left.000 \mathrm{~kg} \mathrm{ha}^{-1}\right)$ of different cultivars and mulch treatments in the harvests in 2000-2002.

\begin{tabular}{|c|c|c|c|c|c|}
\hline Cultivar /Mulch in 2000 & 19-21 Jul & 29 Aug -1 Sep & & & Total \\
\hline "Tavallinen" & 5.63 & $14.13 \mathrm{ab}$ & & & 19.76 \\
\hline "Hankoniemi" & 5.37 & $14.43 \mathrm{a}$ & & & 19.80 \\
\hline ‘Finbladet' & 4.72 & $12.98 \mathrm{ab}$ & & & 17.70 \\
\hline ‘Triumf' & 5.17 & $13.35 \mathrm{ab}$ & & & 18.53 \\
\hline 'Grolau' & 5.15 & $14.33 \mathrm{a}$ & & & 19.47 \\
\hline 'Wilau' & 5.26 & $12.30 \mathrm{~b}$ & & & 17.57 \\
\hline$S E M$ & 0.337 & 0.473 & & & 0.622 \\
\hline Mulch & 4.81 & 13.17 & & & 17.97 \\
\hline No mulch & 5.63 & 14.00 & & & 19.63 \\
\hline SEM & 0.239 & 0.356 & & & 0.385 \\
\hline$P($ Mulch $)$ & 0.041 & 0.185 & & & 0.043 \\
\hline$P$ (Cultivar) & 0.410 & 0.008 & & & 0.030 \\
\hline$P(M \times C)$ & 0.406 & 0.922 & & & 0.860 \\
\hline Cultivar/Mulch in 2001 & 21 May & 2-3 Jul & $31 \mathrm{Jul}-1 \mathrm{Aug}$ & 3-4 Sep & Total \\
\hline "Tavallinen" & $5.18 \mathrm{a}$ & $6.07 \mathrm{a}$ & 10.40 & $10.12 \mathrm{a}$ & $32.07 \mathrm{a}$ \\
\hline "Hankoniemi”" & $5.61 \mathrm{a}$ & $5.95 \mathrm{ab}$ & 9.98 & $9.17 \mathrm{ab}$ & $31.12 \mathrm{ab}$ \\
\hline 'Finbladet' & $3.82 \mathrm{bc}$ & $5.10 \mathrm{~b}$ & 9.48 & $8.74 \mathrm{ab}$ & $27.36 \mathrm{~b}$ \\
\hline ‘Triumf’ & $3.56 \mathrm{c}$ & $5.49 \mathrm{ab}$ & 9.53 & $8.54 \mathrm{~b}$ & $27.72 \mathrm{ab}$ \\
\hline ‘Grolau’ & $4.80 \mathrm{ab}$ & $5.81 \mathrm{ab}$ & 10.34 & $9.48 \mathrm{ab}$ & $31.05 \mathrm{ab}$ \\
\hline ‘Wilau' & $3.17 \mathrm{c}$ & $5.25 \mathrm{ab}$ & 9.88 & $8.85 \mathrm{ab}$ & $27.52 \mathrm{~b}$ \\
\hline$S E M$ & 0.355 & 0.252 & 0.355 & 0.632 & 1.372 \\
\hline Mulch & 5.42 & 5.90 & 10.25 & 10.33 & 32.74 \\
\hline No mulch & 3.30 & 5.32 & 9.63 & 7.97 & 26.21 \\
\hline SEM & 0.284 & 0.189 & 0.265 & 0.764 & 1.139 \\
\hline$P($ Mulch $)$ & 0.013 & 0.041 & 0.197 & 0.117 & 0.017 \\
\hline$P$ (Cultivar) & $<0.001$ & 0.009 & 0.255 & 0.046 & 0.005 \\
\hline$P(M x C)$ & 0.021 & 0.359 & 0.293 & 0.425 & 0.443 \\
\hline Cultivar/Mulch in 2002 & 21-22 May & 26 Jun & 24-26 Jul & 20-21 Aug & Total \\
\hline "Tavallinen" & $6.54 \mathrm{ab}$ & $7.16 \mathrm{ab}$ & 6.14 & 6.07 & 25.89 \\
\hline "Hankoniemi" & $7.46 \mathrm{a}$ & $7.72 \mathrm{a}$ & 6.69 & 7.06 & 28.92 \\
\hline 'Finbladet' & $5.42 \mathrm{bc}$ & $6.13 \mathrm{~b}$ & 6.04 & 6.47 & 24.06 \\
\hline 'Triumf' & $4.73 \mathrm{bc}$ & $6.62 \mathrm{ab}$ & 5.96 & 6.25 & 23.56 \\
\hline ‘Grolau’ & $6.21 \mathrm{ab}$ & $7.06 \mathrm{ab}$ & 6.54 & 6.52 & 26.33 \\
\hline ‘Wilau’' & $4.26 \mathrm{c}$ & $6.56 \mathrm{ab}$ & 6.56 & 6.79 & 24.17 \\
\hline SEM & 0.450 & 0.322 & 0.504 & 0.531 & 0.143 \\
\hline Mulch & 5.81 & 7.43 & 6.90 & 6.57 & 26.70 \\
\hline No mulch & 5.73 & 6.32 & 5.75 & 6.48 & 24.27 \\
\hline SEM & 0.260 & 0.186 & 0.443 & 0.419 & 0.993 \\
\hline$P($ Mulch $)$ & 0.826 & 0.024 & 0.089 & 0.872 & 0.100 \\
\hline$P($ Cultivar $)$ & $<0.001$ & 0.026 & 0.604 & 0.664 & 0.050 \\
\hline$P(M \times C)$ & 0.216 & 0.523 & 0.927 & 0.717 & 0.663 \\
\hline
\end{tabular}

Cultivar means followed by a common letter do not differ significantly $(\mathrm{P}=0.05)$. Probability values $(\mathrm{P})$ are given for the effects of cultivar, mulch and their interaction. $\mathrm{SEM}=$ standard error of the mean.

highest saleable proportion, and in the fourth yield, cultivars Triumf, Finbladet and Wilau. In the last year, quality differences were statisti- cally significant only in the second yield in which 'Triumf' and 'Finbladet' showed the best quality. The data do not provide any clear trends in 
Vol. 12 (2003): 95-105.

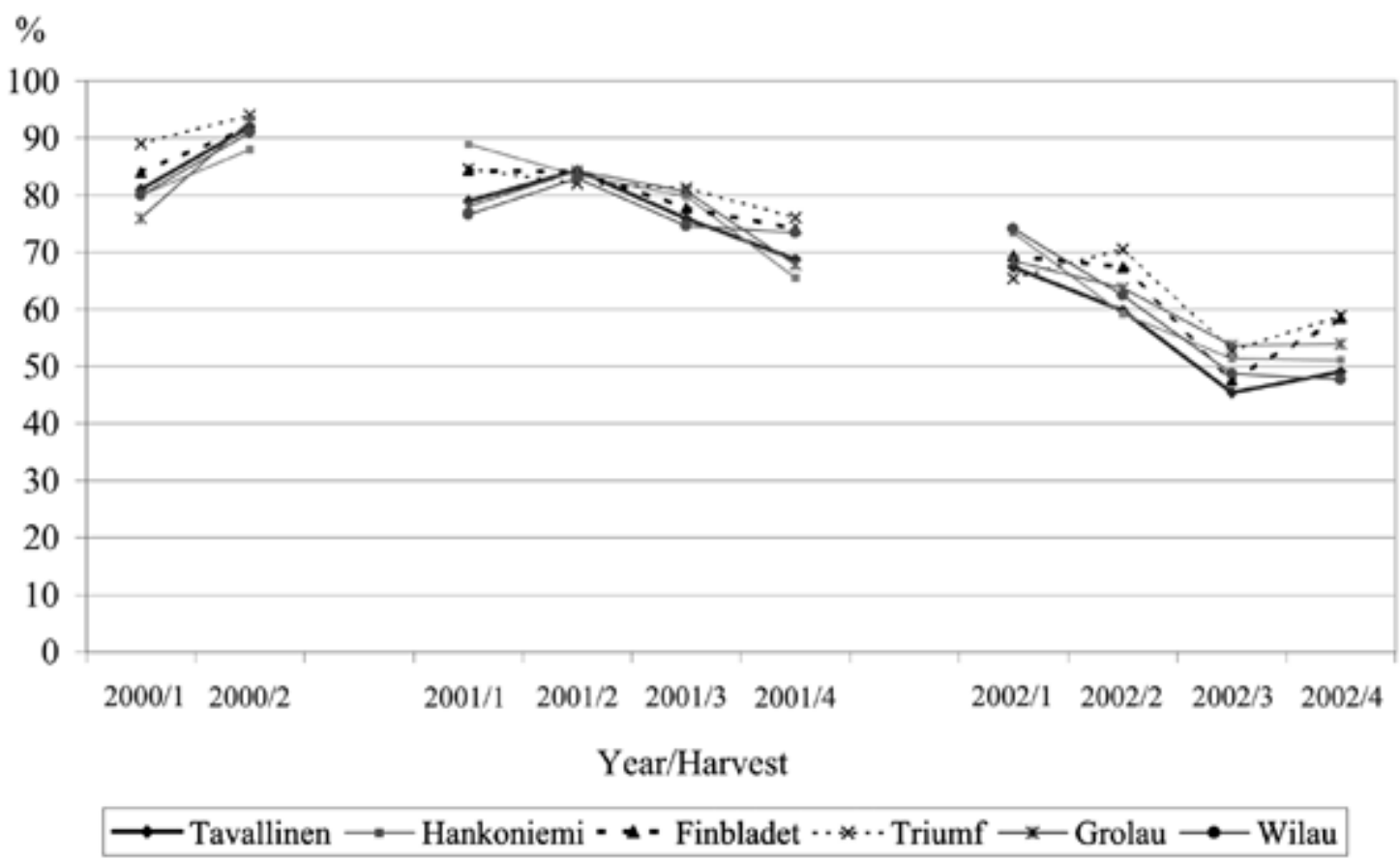

Fig. 1. Saleable proportions ( $\%$ of total yield) of different cultivars in mulched plots.

yield quality between cultivars, but whenever differences were observed, cultivars Triumf and Finbladet were usually of better quality than the other cultivars or populations.

More striking than variation between the cultivars was the sharply decreasing trend in yield quality towards the end of the experiment (Fig. 1). In the last two harvests in 2002, only $45-59 \%$ of the yield (SEM 2.7-3.6) was saleable, in comparison with 76-94\% (SEM 1.2-3.4) in the first year. The quality was impaired by dry or yellow leaf tips, light leaf colour or withered leaves.

\section{Fertilisation}

Fertilisation treatments, which started after the first harvest, had a strong effect on the yield (Table 5). Immediately in the second yield in 2000, the higher nitrogen dose increased the yield, while NPK fertiliser slightly decreased yield, in comparison with nitrogen alone. The same phe- nomenon was seen in the first yield in 2001 . Otherwise, the double nitrogen dose increased yield in all harvests in the second and third years, and NPK fertiliser produced higher yield than nitrogen alone in the fourth harvest in 2001 and in the third and fourth harvests in 2002.

\section{Nutrient uptake}

Nutrient concentrations and nutrient uptake in yield were only measured for treatment NPK2. Nutrient concentrations showed some variation between the harvests which, together with the varying biomass accumulation, resulted in differences in nutrient uptake levels (Table 6). In the planting year, when only two yields were harvested, nutrient uptake was quite low in comparison with the amount of nutrients given in fertilisers. In the subsequent two years, the total nutrient uptake in yield was $185-201 \mathrm{~kg} \mathrm{ha}^{-1}$ for nitrogen, 17-20 $\mathrm{kg} \mathrm{ha}^{-1}$ for phosphorus and $123-138 \mathrm{~kg} \mathrm{ha}^{-1}$ for potassium. 
Suojala, T. Yield potential of chive

Table 5. Total yields $\left(1000 \mathrm{~kg} \mathrm{ha}^{-1}\right)$ in the fertilisation experiment.

\begin{tabular}{|c|c|c|c|c|c|}
\hline Fertilisation in 2000 & 19-21 Jul ${ }^{1)}$ & \multicolumn{3}{|c|}{29 Aug - 1 Sep } & Total \\
\hline N1 & 4.32 & 14.59 & & & 18.91 \\
\hline $\mathrm{N} 2$ & 4.54 & 16.99 & & & 21.52 \\
\hline NPK1 & 4.46 & 13.10 & & & 17.56 \\
\hline NPK2 & 4.19 & 14.39 & & & 18.58 \\
\hline$S E M$ & 0.015 & 0.085 & & & 0.092 \\
\hline$P$ & 0.442 & 0.053 & & & 0.054 \\
\hline$N$ vs. $N P K$ & 0.507 & 0.037 & & & 0.036 \\
\hline Single vs. double dose & 0.860 & 0.055 & & & 0.068 \\
\hline Fertilisation in 2001 & 21 May & 2-3 Jul & $31 \mathrm{Jul}-1$ Aug & 3-4 Sep & Total \\
\hline N1 & 7.02 & 5.77 & 9.83 & 9.87 & 32.49 \\
\hline $\mathrm{N} 2$ & 8.22 & 6.69 & 14.70 & 14.06 & 43.66 \\
\hline NPK1 & 6.35 & 6.03 & 10.75 & 10.77 & 33.90 \\
\hline NPK2 & 7.41 & 7.13 & 15.87 & 18.53 & 48.95 \\
\hline$S E M$ & 1.075 & 0.461 & 0.906 & 0.937 & 2.981 \\
\hline$P$ & 0.013 & 0.059 & $<0.001$ & $<0.001$ & 0.001 \\
\hline$N v s . N P K$ & 0.041 & 0.310 & 0.185 & 0.019 & 0.155 \\
\hline Single vs. double dose & 0.005 & 0.013 & $<0.001$ & $<0.001$ & $<0.001$ \\
\hline Fertilisation in 2002 & 21-22 May & 26 Jun & 24-26 Jul & 20-21 Aug & Total \\
\hline N1 & 7.15 & 7.76 & 6.09 & 7.18 & 28.18 \\
\hline $\mathrm{N} 2$ & 11.60 & 12.36 & 8.84 & 8.72 & 41.53 \\
\hline NPK1 & 7.09 & 8.96 & 8.05 & 9.37 & 33.46 \\
\hline NPK2 & 11.66 & 15.23 & 13.14 & 13.47 & 53.49 \\
\hline$S E M$ & 1.185 & 1.310 & 0.673 & 0.738 & 3.519 \\
\hline$P$ & 0.005 & 0.005 & $<0.001$ & $<0.001$ & 0.002 \\
\hline$N v s . N P K$ & 0.998 & 0.111 & 0.001 & $<0.001$ & 0.023 \\
\hline Single vs. double dose & $<0.001$ & 0.001 & $<0.001$ & 0.002 & $<0.001$ \\
\hline
\end{tabular}

Probability values (P) are given for the effect of treatment and for the contrasts (N vs. NPK and single vs. double N dose). $\mathrm{SEM}=$ standard error of the mean.

${ }^{1)}$ Fertilisation treatments started after the first harvest.

\section{Discussion}

Chive, an old traditional herb, turned out to have a considerable yield potential when efficient cultivation practices were used. Due to the significant effect of fertilisation level on biomass accumulation, the potential chive yield may have been approached in the most intensively fertilised treatment of the fertilisation experiment. Therefore, annual biomass yields up to $20000 \mathrm{~kg} \mathrm{ha}^{-1}$ in the planting year and $50000 \mathrm{~kg} \mathrm{ha}^{-1}$ in the subsequent years are achieveable. The saleable yield is not equally high, but even that was estimated to rise to
$15000 \mathrm{~kg} \mathrm{ha}^{-1}$ in the year of planting and to $30000-40000 \mathrm{~kg} \mathrm{ha}^{-1}$ in the following years in good growing conditions. The figures are much higher than the fresh yields typical in Denmark, $7500 \mathrm{~kg} \mathrm{ha}^{-1}$, and New Zealand, $4500 \mathrm{~kg} \mathrm{ha}^{-1}$, as given by Poulsen (1990). However, in New Zealand seeds are collected from the same plants, which lowers the leaf yield. It seems evident that it is not economical to maintain the chive stand for longer than three years, which was also reported by Balvoll (1995), since the quality of yield diminished dramatically towards the end of the experimental period.

In the cultivar experiment, the yield potential of the cultivars and populations was proba- 
Vol. 12 (2003): 95-105.

Table 6. Dry matter and nutrient contents and nutrient uptake of chive (mean \pm standard deviation) in treatment NPK2 (NPK fertiliser, double dose).

\begin{tabular}{|c|c|c|c|c|c|c|c|c|}
\hline \multirow[t]{2}{*}{ Year } & \multirow[t]{2}{*}{ Harvest } & \multirow{2}{*}{$\begin{array}{c}\text { Dry matter, } \\
\%\end{array}$} & \multicolumn{3}{|c|}{ Nutrient content, $\mathrm{mg} \mathrm{g}^{-1}$ dry matter } & \multicolumn{3}{|c|}{ Nutrient uptake in yield, $\mathrm{kg} \mathrm{ha}^{-1}$} \\
\hline & & & $\mathrm{N}$ & $\mathrm{P}$ & $\mathrm{K}$ & $\mathrm{N}$ & $\mathrm{P}$ & $\mathrm{K}$ \\
\hline \multirow[t]{3}{*}{2000} & 1 & $10.8 \pm 0.2$ & $34.4 \pm 2.3$ & $2.71 \pm 0.12$ & $19.7 \pm 1.3$ & $16.2 \pm 0.5$ & $1.3 \pm 0.07$ & $9.3 \pm 0.8$ \\
\hline & 2 & $11.8 \pm 0.8$ & $23.9 \pm 3.1$ & $2.43 \pm 0.31$ & $19.3 \pm 0.8$ & $40.4 \pm 9.1$ & $4.1 \pm 0.99$ & $32.5 \pm 5.2$ \\
\hline & Total & & & & & $56.6 \pm 8.8$ & $5.4 \pm 1.02$ & $41.8 \pm 5.5$ \\
\hline \multirow[t]{5}{*}{2001} & 1 & $12.0 \pm 0.6$ & $32.9 *$ & $2.90 *$ & $21.9 *$ & $29.1 \pm 5.4$ & $2.6 \pm 0.48$ & $19.4 \pm 3.6$ \\
\hline & 2 & $13.2 \pm 0.8$ & $36.7 \pm 3.4$ & $2.96 \pm 0.16$ & $24.6 \pm 1.5$ & $34.3 \pm 5.0$ & $2.8 \pm 0.24$ & $23.0 \pm 2.7$ \\
\hline & 3 & $12.5 \pm 0.9$ & $30.9 \pm 2.9$ & $2.84 \pm 0.26$ & $20.8 \pm 1.5$ & $60.9 \pm 11.3$ & $5.6 \pm 1.02$ & $41.0 \pm 6.6$ \\
\hline & 4 & $10.6 \pm 1.4$ & $31.2 \pm 4.1$ & $2.91 \pm 0.29$ & $20.4 \pm 1.8$ & $60.4 \pm 8.8$ & $5.6 \pm 0.75$ & $39.5 \pm 4.2$ \\
\hline & Total & & & & & $184.8 \pm 24.2$ & $16.6 \pm 1.74$ & $122.9 \pm 12.7$ \\
\hline \multirow[t]{5}{*}{2002} & 1 & $14.2 \pm 0.9$ & $27.5 \pm 2.1$ & $2.50 \pm 0.19$ & $21.3 \pm 1.6$ & $44.9 \pm 10.8$ & $4.0 \pm 0.5$ & $34.3 \pm 4.7$ \\
\hline & 2 & $11.4 \pm 0.7$ & $25.6 \pm 2.5$ & $2.55 \pm 0.09$ & $16.9 \pm 0.4$ & $44.3 \pm 13.9$ & $4.4 \pm 1.2$ & $29.1 \pm 9.0$ \\
\hline & 3 & $11.9 \pm 0.6$ & $32.9 \pm 1.4$ & $3.27 \pm 0.14$ & $22.2 \pm 1.4$ & $51.3 \pm 8.5$ & $5.1 \pm 0.8$ & $34.5 \pm 5.8$ \\
\hline & 4 & $13.1 \pm 0.4$ & $34.1 \pm 1.4$ & $3.39 \pm 0.24$ & $22.7 \pm 1.7$ & $60.0 \pm 11.7$ & $6.0 \pm 1.0$ & $40.1 \pm 8.9$ \\
\hline & Total & & & & & $200.6 \pm 42.8$ & $19.5 \pm 3.33$ & $138.1 \pm 25.0$ \\
\hline
\end{tabular}

* Concentrations were not analysed. Figures are averages from the analyses of other harvests.

bly not fully revealed because the fertilisation apparently was insufficient, in the light of the fertilisation experiment. This is, however, not likely to have interfered with the comparison of cultivars. Cultivars and populations had differences in yield, but externally they looked much alike: it was very difficult to distinguish the cultivars visually in the field. It was also surprising that, in the most productive cultivars, there was only one proper cultivar while the other two "cultivars" were actually cultivated populations. The Finnish natural population Hankoniemi was one of the most productive populations which may reflect its good adaptation to the Finnish climate.

The use of plastic mulch as ground cover increased the total yield during the growing cycle. Surprisingly, the first yield after planting was lower in mulched plots. A possible reason for this yield decrease may be the excessively high temperature in the root layer under the black plastic. Although the weather was not very warm in early summer 2000 , there were 23 days with maximum temperature over $20^{\circ} \mathrm{C}$ and three days with maximum temperature over $25^{\circ} \mathrm{C}$ before the first harvest. Apart from the negative influence in the planting year, plastic mulch resulted in such a notable yield increase in the following years that it can be regarded beneficial to growth. Further positive effects of mulch include a considerable saving of work in manual weed control (no herbicides are allowed on chive in Finland) and the even moisture content in soil.

The fertilisation experiment revealed the high nutrient demand of chive when producing a great biomass. The nutrient status of the soil, especially its potassium content, was only moderate in the beginning of the experiment, and it continuously decreased over the years (Table 1). In addition, mineral nitrogen content in soil remained low after the first autumn (data not shown). In these conditions, the fertilisation programme with a higher dose of NPK fertiliser seemed suitable. In soils with higher initial nutrient status, lower amounts of fertilisers may be sufficient. Wilson (1995) reported that nitrogen application of $67 \mathrm{~kg} \mathrm{ha}^{-1}$ produced the highest yield when only one yield was harvested in the planting year. Hartmann (1966) found that high nitrogen supply 5-6 weeks after planting inhibited division of plants which resulted in reduced growth. Later in the season, high nitrogen level (up to the annual rate of $300 \mathrm{~kg} \mathrm{ha}^{-1}$ ) favoured growth and improved leaf colour.

The importance of using a NPK fertiliser, 
rather than nitrogen alone, became more evident towards the end of experiment, which coincided with the weakening nutrient status in soil. In the first two harvests after the start of fertigation, NPK fertilisers, however, slightly decreased the yield. This is difficult to explain, since the nutrient solutions were not very strong, nor were nutrient contents or electrical conductivity in soil high. Although in soils with higher nutrient reserves, high yield could be achieved by using nitrogen fertiliser alone after the first harvest, usage of a compound fertiliser might ensure better yield quality. For example, the importance of adequate supply of magnesium has been stressed in literature (Poulsen 1990). The effect of fertilisation on yield quality was not analysed in our experiment, but according to subjective observations, there were no clear differences in the overall quality between the treatments. In the last harvest in 2001, plants from the most intensively fertilised plots (treatment NPK2) started to fall down, which was not observed in the other harvests. Grading of chive after harvest is very time-consuming, wherefore any efforts to improve the external quality, e.g., by nutritional aids, should be further studied.

In the years following the planting, nitrogen uptake in yield was roughly the same as the amount given in fertilisers the same year, phosphorus uptake was $50-65 \%$ of the amount in fertiliser, and potassium uptake was approximately $90 \%$ of the amount in fertiliser. Thus, the fertiliser efficiency was high.
Fink et al. (1999) reported that chive yield of 35 tons ha-1 took up $175 \mathrm{~kg} \mathrm{ha}^{-1}$ of nitrogen, $21 \mathrm{~kg} \mathrm{ha}^{-1}$ of phosphorus and $158 \mathrm{~kg} \mathrm{ha}^{-1}$ of potassium. In comparison with these figures, nitrogen and phosphorus uptakes in our experiment were at similar levels, while potassium uptake was especially low, although the yield was higher than in the report of Fink et al. (1999). This allows us to assume that potassium uptake was weakened by the low potassium content in soil. Leaf nitrogen and potassium concentrations in our study are also much lower than those measured by Wilson (1995).

In conclusion, chive is a productive and winter-hardy herb the commercial production of which could well be increased in Finland. Cultivars showed some differences in biomass production, and a Finnish population originating from the Southern coast was among the bestyielding cultivars. Black plastic mulch is recommended as ground cover. Chive biomass production is highly responsive to nutrient supply. Therefore, soils with good nutritional status should be preferred and sufficient nutrient levels should be applied in fertilisation.

Acknowledgements. I wish to thank the members of the field vegetable team at Piikkiö for their skillful work, Yrkeshögskolan Sydväst for the financial support, Janne Pulkkinen of Kemira GrowHow Ltd. for planning the fertilisation programmes, and Tapio Salo and Leena Mäkäräinen of MTT Soils and Environment for conducting the nutrient analyses.

\section{References}

Balvoll, G. 1995. Grønsaksdyrking på friland. 5th ed. Oslo: Landbruksforlaget. $360 \mathrm{p}$.

Fink, M., Feller, C., Scharpf. H.-C., Weier, U., Maync, A., Ziegler, J., Schlaghecken, J., Paschold, P.-J. \& Strohmeyer, K. 1999. Aktuelle Daten für Düngungsempfehlungen und Nährstoffbilanzen. Gemüse 10/1999: 576-578.

Hartmann, H.D. 1966. Stickstoffdüngungsversuche zu Schnittlauch. Gartenbauwissenschaft 31: 51-63.

Littell, R.C., Milliken, G.A., Stroup, W.W. \& Wolfinger, R.D. 1996. SAS ${ }^{\otimes}$ System for Mixed Models. Cary, NC: SAS Institute Inc. 633 p.
Poulsen, N. 1990. Chive Allium schoenoprasum L. In: Brewster, J.L. \& Rabinowich, H.D. (eds.). Onions and allied crops. Vol. III. Boca Raton: CRC Press. p. 231250.

Tatlioglu, T. \& Wricke, G. 1980. Genetisch-züchterische Untersuchungen am Schnittlauch (Allium schoenoprasum L.). Gartenbauwissenschaft 45: 278-282.

Wilson, H. 1995. Yield responses and nutrient uptake of chive as affected by nitrogen, phosphorus, and potassium fertilization. Communications in soil science and plant analysis 26, 13\&14: 2079-2096. 
Vol. 12 (2003): 95-105.

\title{
SELOSTUS
}

\section{Lajikkeen, muovikatteen ja lannoituksen vaikutus ruohosipulin satoon}

\author{
Terhi Suojala \\ MTT (Maa- ja elintarviketalouden tutkimuskeskus)
}

Ruohosipuli on monivuotinen ja Suomessa luonnon-
varainen yrttikasvi. Ruohosipulin kaupallinen tuotan-
to on maassamme hyvin vähäistä, ja yrttiä tuodaan
runsaasti maahan. Tästä heräsi kiinnostus selvittää
mahdollisuuksia tuottaa kasvia tehokkaasti nykyaikai-
silla viljelymenetelmillä. Lajikkeen, maanpinnan kat-
teen ja lannoituksen vaikutuksia ruohosipulin satoon
tutkittiin kolmivuotisissa kenttäkokeissa. Tutkitut la-
jikkeet voitiin jakaa kahteen ryhmään: satoisimmat
lajikkeet (kotimainen luonnonkanta Hankoniemi, hol-
lantilainen viljelykanta Tavallinen ja saksalainen la-
jike Grolau) tuottivat $10-20 \%$ korkeammat sadot
kuin muut lajikkeet. Sadon laadussa ei ilmennyt sel- viä lajike-eroja. Musta muovi maanpinnan katteena lisäsi satoa ja helpotti rikkakasvien hallintaa sekä maan kosteuden säilymistä. Peruslannoituksen jälkeen viikottainen kastelulannoitus moniravinteisella lannoitteella ja korkeammalla typpimäärällä (10$15 \mathrm{~kg} / \mathrm{ha} \mathrm{N}$ viikossa) tuotti suuremman biomassan kuin pelkän typpilannoitteen ja/tai puolet alemman typpimäärän käyttö. Istutusta seuraavina vuosina sadon mukana poistui typpeä $185-200 \mathrm{~kg} / \mathrm{ha}$, fosforia $17-20 \mathrm{~kg} / \mathrm{ha}$ ja kaliumia $120-140 \mathrm{~kg} / \mathrm{ha}$ eniten lannoitetussa ja suurimman sadon tuottaneessa käsittelyssä. Tulosten mukaan ruohosipuli on nykyaikaisilla viljelymenetelmillä satoisa kasvi. 
